\title{
Embracing Make Believe Play and Theories of Childhood: Understanding Children's Spirituality and the Spiritual Essence of a Young Child
}

\author{
Kathleen I. Harris
}

Division of Education, Early Childhood Education/Early Intervention, Seton Hill University, USA

\begin{abstract}
Young children are born with a unique developmental path that captures the spiritual essence of wonder and each child's signature style of their own capabilities, strengths, interests, personality, temperament, and learning styles. Spiritual moments experienced by young children are often direct, personal, and have the effect, if only for a moment, of uplifting the child by capturing the essence of spirituality through playful moments. Children's spirituality involves questioning, exploring, and belonging by building close relationships in comfortable environments and with caring caregivers who provide a secure environment and routine in which to grow. Spirituality, together with the ability to make-believe allows young children to be awakened with an awareness of community and purpose for the world around them. Each new discovery made by a young child is a potential source of wonder and delight. Through a child's imagination and make-believe play, teachers and parents may be given opportunities to witness children's spirituality. In this article, children's spirituality is defined and the characteristics of spirituality are discussed. The dynamics of play for young children and the contributions of major early childhood theorists to the growth and understanding of children's spirituality are featured.
\end{abstract}

Keywords: Spirituality, Play, Early childhood, Theorists, Relationships.

\section{INTRODUCTION}

The sun shone brightly between fluffy summer clouds on an early June afternoon as a mother and two children enjoyed a summer walk at a suburban park. The stroller was going at a slow pace around each bend and down the hill near the lake. Three-year-old Josie, the older daughter, slowly followed her own shadow and watched the geese, birds, and glimmering rocks that sparkled while she walked with tiny steps on the path. Taking a turn towards the lake, Josie suddenly stopped, leaned over, and reached her small hands out so she would gently fall on the ground and her tiny body would follow as she knelt down and looked at a small fish that had jumped from the water onto the hot pavement. Her mother looking around, smiled and said, "Josie, come on. We need to finish our walk."

"I can't leave now Mommy. Come back! Look! It's a fish, and it's smiling at me!"

"Josie, let's keep walking," explained her mother.

"In a minute, Mommy. The fishie is smiling at me."

"Address correspondence to Kathleen I. Harris, Division of Education, Early Childhood Education/Early Intervention, Seton Hill University, USA; Tel: 724-830-1035; E-mail: kharris@setonhill.edu
The spirit of wonder typically presents youngsters with something so much greater than themselves; it offers an environment where they can contemplate infinity and eternity. During early childhood, an ecological awareness of the natural universe through imagination and attention to nature is just one developmental issue in studying children's spirituality. In this paper, spirituality is defined and discussed, connecting the joy of make-believe play for young children and the contributions of major early-childhood theorists to the growth and understanding of children's spirituality.

Childhood is often viewed as a unique period that prepares the youngster for adult life [1]. The emerging field of spirituality has enormous potential to achieve a key goal-to understand the developing child who grows outward in small steps or sudden sprints while proceeding ever more steadfastly on his or her own journey towards adulthood [2]. Like growth in other dimensions of life, growth in the spiritual domain follows a broadly recognizable pattern that includes emotional, cognitive, social, and moral interpretations and responses according to early childhood theorists [3].

In the last few years, there has been an increasing interest, and awareness, in the whole area of spirituality in education [4]. Part of this stems from 
the perception that spirituality is an inherent part of human existence and cannot be ignored in educational settings. Unless the development of the mind and body go hand in hand with a corresponding awakening of the soul, the former alone would be a poor, lopsided affair [5]. What exactly is spirituality? Globally, a concern has grown with regard to spirituality in the general public as well as among scholars [6]. Any discussion of spirituality can become a very complicated conversation. Difficult to define, the term spirituality is a broad concept used in many ways in modern society. Writings on the spirituality of children also vary widely in their descriptions and assumptions about spiritual experiences [7]. Spirituality, like identity, frequently emerges as an important concept when education and personal development are considered [8].

Spirituality is the craving deep within each human being for meaning. This feeling or experience emerges from time to time when people encounter shades of orange, red, and purple of a sunset or the stage of a magical summer evening, or when Josie, examined the smile and texture of a fish that appeared while she was out walking with her mom and baby sister. Spirituality is manifested in ordinary human activities and concerns, and its definition embraces the ways in which people look for and perceive meaning, purpose, and values, as well as other qualities like beauty, appreciation of nature, fulfillment, happiness, and community [8]. Spirituality influences how people think together, what they value, how they act, and especially, where they place their trust. Beginning at birth, spiritual development involves changes and continues to evolve over each stage of growth. Supporting the development and education of the "whole child," includes consideration of children's spirituality [9].

Children's spirituality is inwardly intrinsic and involves growth and change. Because growth and development constantly change, it is impossible to avoid addressing children's spirituality every day in every early childhood classroom. Children seem to reveal a natural spirituality in their sense of wonder, their fantasies and imagination, their play, and their spirit of curiosity [10]. The continual growth of a child's spiritual development begins at infancy and continues throughout adolescence. Changes shape and uplift all areas of a child's holistic, whole development. Spirituality is the human capacity for transformation in which the individual participates, and goes through passages [11].

According to John Dewey, when we view education as growth, we come to see the child "intrinsically" rather than "comparatively" [12]. The school and home, rooted in spirituality, are places that children, teachers, and families feel intrinsically connected; it includes every aspect of being "whole" for a young child. They are also experiencing authentic learning that is not focused on what will be on the next test. Instead, it is learning that leads to a deep sense of joy and fulfillment. Learning from a spiritual perspective is radically different from present approaches to education [13]. This perspective in teaching requires compassion and responsibility for all beings, including oneself. As a result, all children learn virtues in ways that help to maintain positive relations with others, especially with those who share the aim of establishing caring relationships [14].

Children's spirituality is embedded in meaningful relationships and is actively nurtured for the child, the family, and the larger community, including all peers, teachers, and health professionals. Providing a meaning for participation, spirituality evokes feelings of hope, trust, and inspiration, embodying the human emotion to be connected with something larger than our own egos [15]. Based in consciousness, children's spirituality is universal and characterized by an inner peace. Referring to something more than being alert and mentally attentive, this consciousness is a distinctly reflective meta-cognition, and a degree of awareness on the part of a child of the remarkable nature of his or her mental activity in certain contexts [16].

Finally, children's spirituality enjoys unprecedented freedoms for all young children, to wonder, make new discoveries, experiment, and create new possibilities in their world. The spiritual experiences of children reflect the wide variety of ways they can respond to different environments [7]. As a result, children's feelings, beliefs, attitudes, and experiences, make spirituality a multidimensional 
construct. To understand children's spirituality fully in a valid and complete, holistic way for all children, methodology must account for the multiple ways children perceive, experience, and express spirituality [2].

A growing body of evidence suggests that children have spiritual capacities and experiencesmoments, both little and large that shape their lives in enduring ways. Spiritual moments are direct, personal, and often have the effect, if only for a moment, of awakening a person to questions about identity and place in the universe. Furthermore, spiritual moments can serve as benchmarks and catalysts for spiritual growth (Figure 1) [17]. A dynamic aspect of a child's spiritual development involves childhood consciousness, which includes creative aspirations, spiritual and aesthetic qualities and values, intuitive inspirations, greater critical self-awareness, and reflective living [18]. Opportunities for spiritual growth may happen by surprise. Only the child having the experience can determine whether or not it is spiritual. What one child may deem spiritual, another may define in different terms [19]. Spiritual moments allow all young children to discover the undiscovered in human potential and acknowledge what is unknown and can only be disclosed in a free future [20].

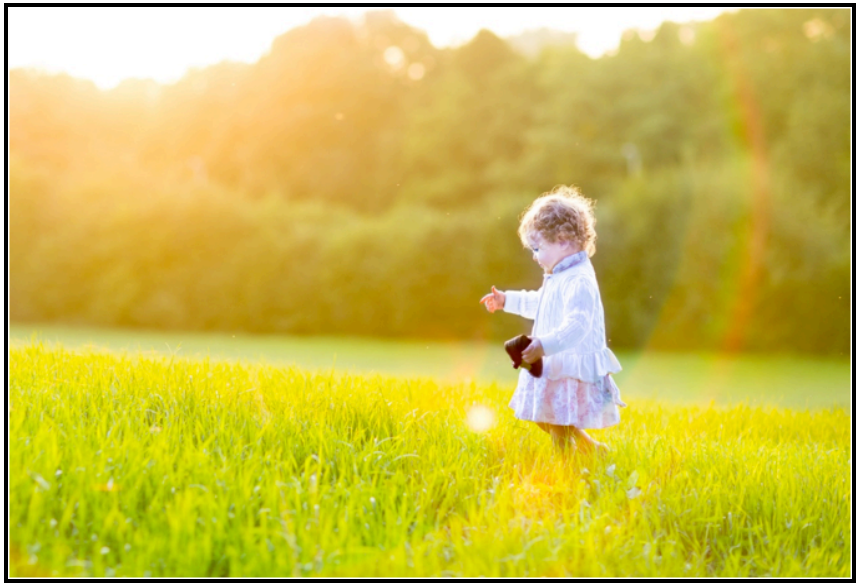

Figure 1. Spiritual moments experienced by young children are often direct, personal, and have the effect of uplifting a child by capturing the essence of spirituality through playful moments. Each new discovery made by a young child is a potential source of wonder and awe.
Hay and Nye asserted that children's spirituality features three distinct dimensions, including awareness-sensing, mystery-sensing, and valuesensing [16]. Awareness-sensing involves a child focusing on the here-and-now during an aesthetic experience or meditation, and is often marked by intense focus and concentration on the present moment [7]. For example, awareness-sensing occurs frequently when a young children engages in dramatic play. Before a tea party can be served for friends, for example, the table must be set, cookies baked, and guests (other peers) invited to attend. Supporting role-playing and encouraging young children to take on specific roles and responsibilities with peers during dramatic play connects to the spiritual disposition of awarenesssensing. During dramatic play, the child's attention becomes increasingly focused on the action or fantasy. This type of pretend play has the potential to connect the child's soul and mind (Figure 2). As both connect with one another, the power of play for a young child is awakened with new discoveries, knowledge, and skills. The life of a young child is filled almost daily with the mastery of new skills, such as crawling, walking, speaking, learning to problem solve, read, and write. In fact, awareness-sensing is very familiar for young children [16].

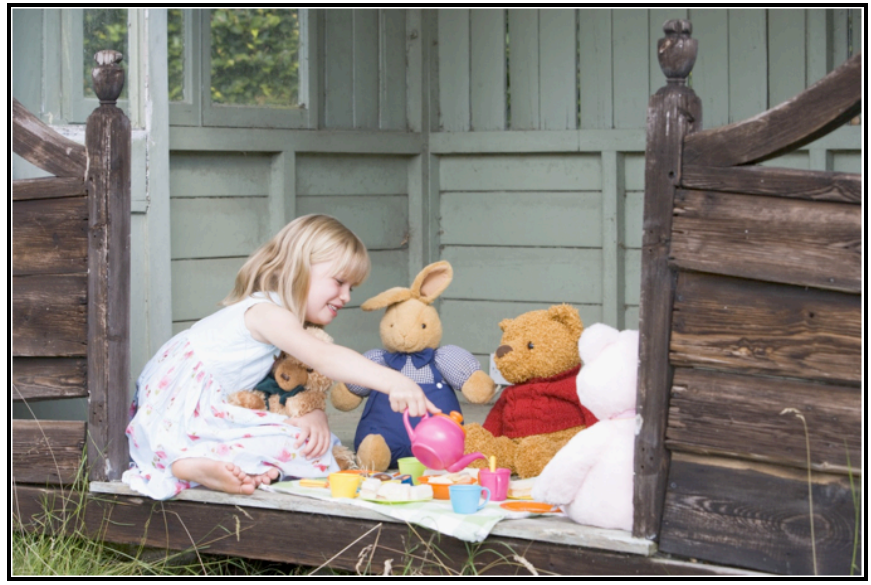

Figure 2. During dramatic play, a child's attention becomes increasingly focused on the fantasy. Dramatic play connects the soul and mind by giving children opportunities to be creative, use their imaginations, and master new skills. 
The spiritual experiences of children can also be considered mystery-sensing. Mysterious because they are associated with life's ultimate mystery, characterized by wonder, awe, and a highly imaginative state far beyond what is typically experienced in daily life [7]. Childhood is a time of wonder and awe, as the world captures the attention of a young child through their fresh eyes and ears [17]. This type of sensing refers to the wonder, fascination, and questioning that is characteristic of young children as they interact with their universe. When young children engage their sense of wonder, they may express something of their spirituality [21]. Experiences that include items from nature and allow time for appreciation of the natural world connect to mystery-sensing. Educators and health professionals can provide opportunities for children to encounter new experiences and to ask open-ended questions. They can allow for individual expression during dramatic play and also share storytelling, especially those encouraging questions and wonder along with picture books that reflect the interests, backgrounds, and individual differences of young children. A reflection that signifies to a young child "I wonder" is often the verbal stance that initiates this mystery of wonder and awe. These types of open-ended inquiries uncover an awakening to a particular subject, interest, or topic for a young child, who early senses that much of life is incomprehensible, and therefore, mysterious [16].

The intrinsic power of play is grounded in a sense of awe and wonder for all young children. Play contributes to the wonder and mystery. All children play as they do because they are learning how to live in the world. They are experimenting with life and developing (through trial-and-error) faculties that will enable them to thrive as they grow and develop [22]. Play is not frivolous, rather it greatly enriches children in all developmental domains, including the spiritual domain. Makebelieve play offers tremendous opportunities for wonder, which ranges from awe-inspiring spiritual epiphanies to small moments of being overwhelmed by the color or fragrance of a flower [17]. Wonder surfaces when a child observes leaves falling from trees in autumn and tells a teacher the tree is slowly getting tired, or the first time a child observes snowflakes in winter, or plays with his or her shadow outdoors. These types of mysterysensing moments are timeless. Tillich wrote of the ability to be lost in the moment, to absorb what is happening, and to have the capacity to be open to new perceptions [23]. Knowing is not half as important as feeling. A child's world is full of wonder and excitement. Every mystery solved brings the individual to the threshold of a greater mystery [24].

Imagination and creativity are also claimed as expressions of, or forms of, mystery-sensing [25]. Imagination can be regarded as a critical feature of human cognition and information processing [26]. Imagination is a means by which young children are able to make meaning and sense of their experiences. The free use of imagination is evident in children's play, where an old cardboard box can become a car, house, or spaceship. Imagination provides a powerful way to discover meanings and values in response to children's experiences. Imagination may involve elaborated verbal sequences conducted privately in consciousness, or it may take on story-life-forms, such as a reminiscence or wished-for future sequence of events [26].

Fundamental to learning, imagination is a cognitive capacity [27]. Imagination is a means by which all young children, both typically developing and children with disabilities, are able to make meaning and sense of their experiences. Imagination creates new discoveries, wonder, inventions, not just in education, but also in life [27]. Dewey considered imagination as the ability to look at things with different lenses as if they could be otherwise [12]. For young children, imagination creates new adventures in play and makes life joyful. Conscious imaginative play for young children reaches its peak from age three to six. Studies of children's ability to enter into fantasy in make-believe play show that children have a powerful capacity for (and enjoyment of) letting go of material reality. When used sensitively, work with the imagination provides a powerful way to discover meanings and values in response to children's experiences, especially experiences for which their language is inadequate [16]. Imagination provides young children with opportunities to 
transcend the ordinary and discover for themselves the meanings and values of their experiences. The mystery-sensing created in imaginative acts is perhaps as significant in children's responses as what religion is to adults [16]. In children's imagination, seen in their artwork, dramatic play, stories with peers during social play, and even perhaps through their fears, others can gain a glimpse of the mystery of their spirituality. It is during this type of make-believe play that the union of a child's soul and mind emerges.

The third dimension of children's spirituality is value-sensing, which is experienced via emotion [16]. Donaldson suggested that spiritual enlightenment is an advanced outcome of the education of value-sensing and that this is a link with the way children express their ideas of value in the intensity of everyday experiences of delight and despair [28]. Value-sensing is characterized by a quest for meaning, trust in life, and affirmation of ideas of value or worth expressed in feelings of delight or despair [7].

Value-sensing is also credited with providing a sense of goodness to young children that allows them to have a basic trust in being. During makebelieve play, children foster a value of sensing and goodness, learning the social skills of sharing, taking turns, and cooperating with one another [29]. A number of research studies have shown that young children who have more opportunities to engage in make-believe play develop more positive emotions and identify an adverse relationship between imaginative play skills and overt manifestations of anger and aggression [26]. Encouraging children to respect one another's ideas and contributions to play, promoting sharing and turn-taking through modeling, and giving children responsibility for caring for materials, toys, and pets also contribute to value-sensing. Furthermore, inviting children to express their thoughts, and involving all children in establishing rules for community building and respectful listening and talking are important during the early childhood years.

Empathy, which supports goodness in children as well as value-sensing, has been described as the basis of moral development, and as the trait that makes us most human [30,31]. Empathy awakens human interconnection, compassion, and love [17]. Young children's pro-social behaviors may be motivated by empathy, for example, when a young child plays doctor and puts a bandage on another child who has an imaginary injury, or when a peer is the victim of imaginary danger [32]. Theories of mind about empathic motives, expressed by consistent predictions, are related to young children when sharing a snack and helping a friend in distress during play [32]. Research has also shown that all young children are motivated by empathy. For example, when Zahn-Waxler observed the reactions of toddlers to stimulated distress in their mothers, she found that toddlers in turn cried and looked distressed [33]. Research has also indicated that young children who serve as peer intervention agents possess a capacity for empathy-motivating prosocial behavior, such as kindness, forgiveness, and compassion for individual differences [34]. With establishing and maintaining a sense of classroom community within the curriculum, educators implicitly convey to children that they value relationships and healthy interdependence. One way teachers can promote this philosophy in the classroom is to become familiar with early childhood theorists who described the foundations of growth and development. Nourishing the growth of children in all aspects of their lives requires an understanding of human development [7]. Like many dimensions of our lives, faith seems to have a broadly recognizable pattern of development.

A number of child theorists have contributed to current understanding of children's spiritual development, including Erik Erickson [35]. Erickson studied psychosocial development across a lifetime and identified conflicts and crises that are experienced at various stages of development. His work indicated that normal development does not follow a set pattern over time, and acknowledged the importance of trusting relationships and attachments for young children. Jean Piaget studied cognitive development and theory of mind for understanding how young children think [36]. Lev Vygotsky's studies concerning language and thought highlighted the connection between social/cultural interactions and cognitive develop- 
ment [37]. Lawrence Kohlberg's identification of levels of moral reasoning and James Fowler's stages of faith development also shed light on the awareness and description of spiritual development $[38,39]$.

James Fowler is largely responsible for opening the door to serious investigation of faith development as a critical piece of human development [40]. Faith is a basic human quality defined as a dynamic pattern of trust in and loyalty to a center of value and to an image of power. Faith involves all of these aspects of human development, and movement from one stage to another, and is not automatic or assured [3]. Fowler's stages of faith seem to reflect the spiritual path of many children raised in Western Christian families [40]. This serves as a reminder for educators to be considerate about expecting children with different backgrounds to fit into certain developmental theories.

Fowler pioneered contemporary spiritual development in the 1980s, describing eight stages of spiritual development starting with infancy and ending with a universal faith, much like Lawrence Kolberg's moral development stages [38,39]. In Fowler's view of development, the infant stage is a preliminary stage during which children learn about a spiritual self by discovery and basic trust in people. As young children grow in their ability to form relationships and develop empathy and reciprocity, they also grow in spirituality. During early and middle childhood growth and development, Fowler's stages of spiritual development continue from two to seven years as the intuitive-projective stages. In young children, gross motor, fine motor, and cognitive development are intertwined processes related to the maturation timetables of the central and peripheral nervous systems. Neurons migrate, proliferate, and make complex connections [3]. Young children explore the use of language, fantasy, and imagination, becoming capable of increasingly sophisticated communications. Their thought processes are more intuitive, holistic, and mood-based. Selfdevelopment continues with the beginning awareness of individual feelings and experiences.

Spirituality during the infant and toddler years builds upon Erik Erickson's theory of trust versus mistrust in early childhood. Erikson believed that at every stage a new miracle unfolds for young children, and this constitutes a new hope and new responsibility for everyone [35]. During the first stage of psychosocial development, a young child's task is to develop a sense of trust in himself or herself, in other people, and in the world around the child. When children develop a strong sense of trust during their first years of life, they are able to form trusting relationships with caregivers and peers.

Trusting and nurturing relationships are important developmental issues for studying children's spirituality. Children's spiritual needs seem to be closely linked with their social and emotional needs [41]. Requiring a sense of trust and security in their environment, all young children thrive on secure, reliable, and consistent care [42]. Their growth in spirituality involves living and belonging, and building close relationships from the trust created in comfortable environments (both at home and school). Caring family members and teachers can provide secure environments with consistency and routine in which children can grow and develop in all areas to their fullest potential. Fowler described these needs in terms of (a) experiencing well-being through belonging, (b) interrelationships characterized by mutual love and trust, and (c) being cherished and loved as unique and irreplaceable [43]. These qualities constitute the essence of sensitive, responsive relationships that foster secure attachments [44]. Attachment is a reciprocal process for both the young child and family [41]. Its importance for a healthy development and competent functioning in children has been well-established [45]. Providing a safe haven for all young children will give them a sense of trust, and nourish their souls to allow opportunities for spirituality to grow and deepen [46].

Cognitively, the toddler is in transition between Piagetian stages [3]. According to Jean Piaget, children's cognitive development enters the preoperational stage, which extends from the second year of life through ages seven or eight [36]. Piaget stated that during the preoperational stage, children are egocentric and can focus only on one characteristic of a thing or a person at a time. Egocentrism is seeing the world only from one's 
own point of view. During this stage, Piaget also believed young children form ideas from their direct experiences in life. They attempt to form images that can hold and order the mixture of feelings and impressions evoked by their encounters with the newness of both everyday reality and the penumbra of mystery that surrounds and pervades it [3]. Imagination, not yet disciplined by consistent logical operations, responds to story, symbol, dream, and experiences.

Theory of mind, or the realization that beliefs do not necessarily match reality, and the reality that different people hold different beliefs about the world, is a part of play development in early childhood [47]. The findings of theory of mind research, therefore, may suggest ways to build a spiritual understanding onto children's developing understanding of their psychological world [48]. From Piaget's perspective, children start out unconscious and with development become increasingly conscious by adopting and constructing new tools for thinking [49]. Piaget also used the term magical causality to describe a type of reasoning in which young children believe in their own efficacy to cause some event merely through the power of their own gestures or thoughts. Young children believing they can obtain some prized toy by wishing for it would be said to be engaged in magical reasoning [50]. Such possibilities imbue this stage with the potential for deep and longlasting emotional and imagined orientations [43].

The realization that a spiritual dimension to all of life colors young children's whole sense of being and their sense of the world leads to the next developmental implication for fostering spiritual development in young children. Kahn perceived nature, which children innately love, as part of a physical and biological reality that bonds their cognition and culture as well as people's psychological structures across cultures [51,52]. The natural attraction to nature connects to children's learning and development. When young children take time to experience the wonder and beauty of nature, they are constructing knowledge, becoming more self-aware of their senses, and making sense of real-life experiences as well as the human social world [53]. During the early childhood years, this love of nature directly affects the intel- lectual activities of children's minds, which ultimately shapes their way of knowing about nature [52]. By encouraging children to nurture a respect and care for the natural universe (through enjoying and investigating the wonder of nature), children are empowered to see themselves as an integral part of the world and universe [54].

\section{IMPLICATIONS FOR EDUCATORS, HEALTH PROFESSIONALS, AND FAMILIES}

Ultimately it is not the skills one learns in math or writing that truly define his/her quality of life, but the friendships that define true participation in one's community. For this to be true, teachers must appreciate those special times when a young child brings a seashell from a holiday vacation to show friends, the excitement in a child's eyes when mixing two paint colors together with a friend at an easel, or the fun of playing with a friend and making sandcastles at the sandbox. By nurturing, supporting, and acknowledging all aspects of childhood consciousness during developmentally appropriate play, educators and health professionals can liberate a child's spirituality.

As educators, we must maintain our vision of the 'holistic,' whole child. Teachers must take time to embrace and celebrate the contributions of early childhood theorists to the curriculum, common core standards, and classroom environments by connecting their theories directly to the spiritual domain of all young children. Teachers should consider modeling wonderment in everyday experiences and provide unique opportunities for children to encounter new experiences. In addition, they should take time to be aware, be creative, and imagine the "what if's" with their children in the classroom by active listening and documentation. Health professionals need to work to become more present, mindful, and caring. Developmentally appropriate interaction between caregivers and children fosters development and nurtures spirituality [9]. In addition, families should enjoy those special times when their children discover the beauty of a rainbow and looks for the pot of gold after a thunderstorm, or enjoy popsicles at the park on a warm summer evening after swinging on a swing and reaching for the stars (Figure 3). Those playful little minds are full of wonder and 
curiosity, which must be savored, for in the blink of an eye, the spiritual essence of a young child will be grown up!

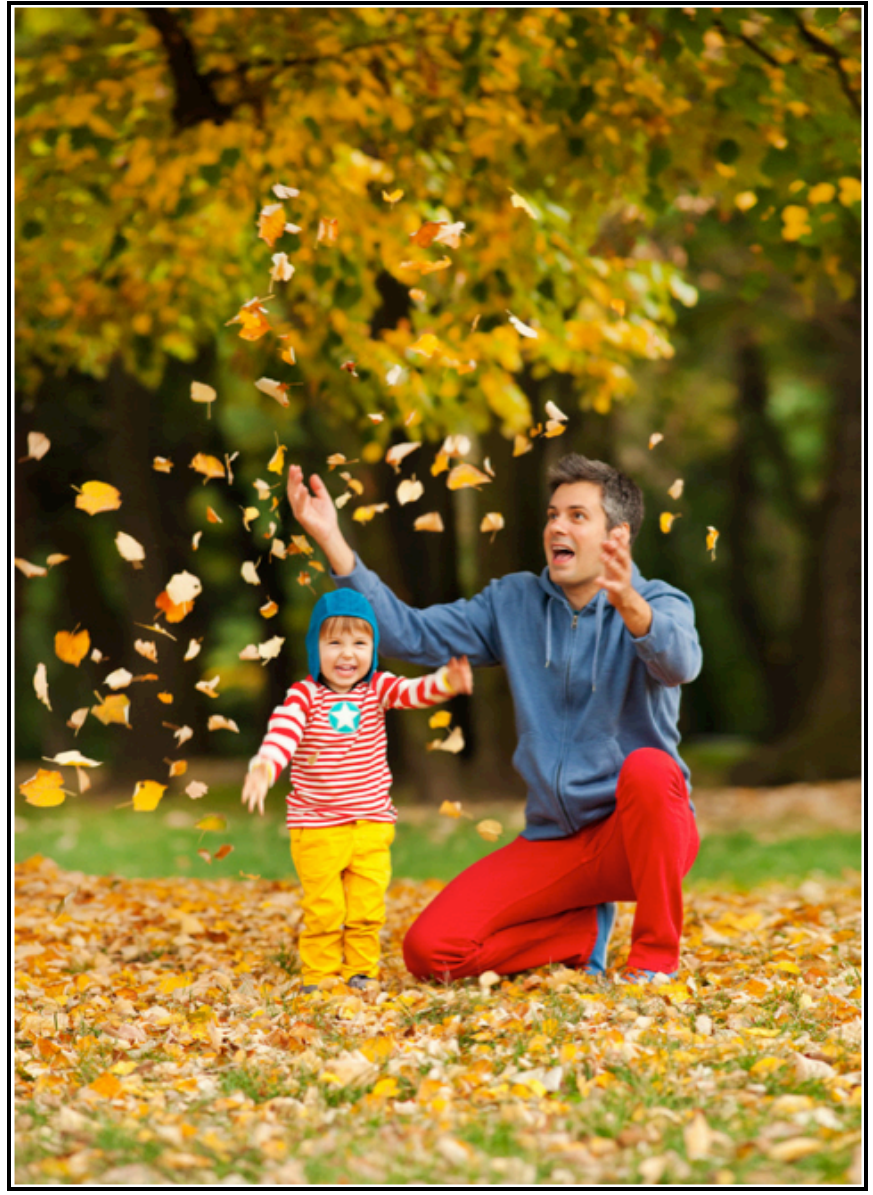

Figure 3. Family members can support a young child's spiritual domain by taking time to enjoy new discoveries together and offering developmentally appropriate play that promotes curiosity and wonder.

\section{CONCLUSION}

Why is the spiritual domain so important in the development of a young child?

Children have a certain degree of hopefulness and optimism throughout childhood (and if nurtured and supported will extend into adolescence and adulthood). This gives children courage, resiliency, humility, and self-acceptance for all individual differences. These dispositions may give evidence and shed light on the diverse ways in which young children pursue their spiritual drives and may help us recognize the innate spiritual capacities in our own life.

\section{REFERENCES}

[1] Estep JR, Breckenridge L. The ecology and social dynamics of childhood spirituality. In: Radcliff D, editor. Children's spirituality: Christian perspectives, research, and applications. Eugene, OR: Cascade; 2004. p. 324-42.

[2] Boyatzis CJ, Newman BT. How shall we study children's spirituality? In: Radcliff D, editor. Children's spirituality: Christian perspectives, research, and applications. Eugene, OR: Cascade; 2004. p. 166-81.

[3] Fowler J, Dell M. Stages of faith from infancy through adolescence: Reflections on three decades of faith development theory. In; Roehlkepartain ED, King PE, Wagener L, Benson PB, editors. The handbook of spiritual development in childhood and adolescence, Thousand Oaks, CA: Sage; 2006. p. 34-45.

[4] King U. The search for spirituality: Our global quest for meaning and fulfillment. Norwich: Canterbury Press; 2009.

[5] Gandhi M. All men are brothers: Autobiographical reflections. New York: Continuum; 1958.

[6] Roehlkepartain EC, Benson PL, King PE, Wagener LM. Spiritual development in childhood and adolescence: Moving to the scientific mainstream. In: Roehlkepartain EC, King PE, Wagener LM, Benson PL, editors. The handbook of spiritual development in childhood and adolescence. Thousand Oaks: Sage; 2006. p. 1-15.

[7] May S, Radcliff D. Children's spiritual experiences and the brain. In; Radcliff $D$, editor. Children's spirituality: Christian perspectives, research, and application. Eugene, OR: Cascade; 2004. p. 149-65.

[8] Crawford ML, Rossiter GM. The future of holistic education: The recession we had to have? Curriculum Perspectives 1993; 13: 37-46.

[9] Baumgartner JJ, Buchanan T. Supporting each child's spirit. Young Children 2010; 55: 90-4.

[10] Halstead JM, Waite S. Nurturing the spiritual in children's sexual development. Int J Child Spiritual 2001; 6: 185-206.

[11] Yust KM, Johnson AN, Sasso SE. Roehlkepartain EC. Nurturing child and adolescent spirituality: Perspectives from the world's religious traditions. New York: Rowman Littlefield; 2006.

[12] Dewey J. Democracy and education. New York: Free Press; 1916.

[13] Miller JP. Learning from a spiritual perspective. In: O'Sullivan E, Morrell A, O'Connor, MA, editors. Expanding the boundaries of transformative learning; New York: Palgrave; 2002. p. 95-102.

[14] Noddings N. Happiness and education. New York: Cambridge University Press; 2003. 
[15] Palmer PJ. The heart of a teacher: Identity and integrity. In; Lieberman A, editor. The JosseyBass reader on teaching. New York: Wiley; 2003. p. 26-37.

[16] Hay D, Nye R. The spirit of the child. Philadelphia: Jessica Kingsley; 2006.

[17] Hart T. Spiritual experiences and capacities of children and youth. In: Roehlkepartain EC, King $P E$, Wagener L, Benson PL, editors. The handbook of spiritual development in childhood and adolescence. Thousand Oaks, CA: Sage; 2006. p 163-77.

[18] Lealman B. The whole vision of the child. In: Best R, editor. Education, spirituality, and the whole child; New York: Cassell; 1996. p. 20-9.

[19] Tisdell EJ. Spirituality, cultural identity, and epistemology in culturally responsive teaching in higher education. Multicultural Perspectives 2006; 8: 19-25.

[20] Webster DH. Spiders and eternity: Spirituality and the curriculum. In: Best R, editor. Education, spirituality, and the whole child. New York: Cassell; 1996. p. 245-59.

[21] Hyde B. Children's spirituality and "The Good Shepherd Experience." Religious Education 2004; 99: 137-50.

[22] Singer I. The harmony of nature and spirit. London: John Hopkins; 1996.

[23] Tillich P. Dynamics of faith. New York: Harper Row; 1957.

[24] Carson R. The sense of wonder. New York: Harper Row; 1956.

[25] Ota C, Erricker C. Spiritual education, literacy, empirical and pedagogical approaches. Portland, OR: Sussex; 2005

[26] Singer S, Singer JL. Imagination and play in the electronic age. Cambridge, MA: Harvard University Press; 2005.

[27] Mulcahey C. The story in the picture: Inquiry and artmaking with young children. New York: Teachers College Press; 2009.

[28] Donaldson M. Human minds. London: Allen Lane/Penguin Press; 1992.

[29] Singer DG. The power of playing together. Scholastic Parent Child 2002; 9:43-7.

[30] Hoffman ML. Empathy and justice motivation. Motiv Emotion 2001; 14: 151-72.

[31] Azar B. Defining the trait that makes us most human. APA Monitor 1997; 28: 1-15.

[32] Ginsburg HJ, Ogletree SM, Silakowski TD, Bartels RD, Burk SL, Turner GM: Young children's theories of mind about empathic and selfish motives. J Soc Behav Pers 2003; 31: 237-44.

[33] Zahn-Waxler C. From the enlightenment to the millennium: Changing conceptions of the moral sentiments. Developmental Psychologist News- letter from Division 7. Washington, DC: APA; 1998.

[34] Eisenberg N. Empathy-related emotional responses, altruism and their socialization. In: Visions of compassion: Western scientists and Tibetan Buddhists examine human nature, Davidson RJ, Harrington A, editors. London: Oxford University Press; 2002. p. 131-64.

[35] Erikson E. Childhood and society. London: Collins; 1965.

[36] Piaget J. The child's conception of physical causality. New York: Harcourt; 1930.

[37] Vygotsky LS. Mind in society: The development of higher mental processes. Cambridge, MA: Harvard University Press; 1978.

[38] Kolberg L. Moral and religious education and the public schools. A developmental view. In: Sizer $\mathrm{T}$, editor. Religion and public education. Boston: Houghton Mifflin; 1967. p 164-73.

[39] Fowler J. Stages of faith: The psychology of human development and the quest for meaning. New York: Harper Collins; 1981.

[40] May S, Posterski B, Stonehouse C, Cannell L. Children matter: Celebrating their place in the church, family, and community. Grand Rapids, MI: William B Eerdmans Publishing; 2005.

[41] Granqvist P, Dickie JR. Attachment and spiritual development in childhood and adolescence. In: Roehlkepartain EC, King PE, Wagener L, Benson PL, editors. The handbook of spiritual development in childhood and adolescence. Thousand Oaks, CA: Sage; 2006. p. 197-210.

[42] Honig A. Secure relationships: Nurturing infanttoddler attachment in early care. Washington, DC: NAEYC; 1992.

[43] Fowler J. Keeping faith with God and our children. A practical theological perspective. Relig Ed 1994; 89: 543-60.

[44] DeWolff MS, van IJzensoorn MH. Sensitivity and attachment: A meta-analysis on parental antecedents of infant attachment. Child Dev 1997; 68: 571-91.

[45] Cassidy J, Shaver PR. Handbook of attachment theory and research. New York: Guilford; 1999.

[46] Stairs J. Listening for the soul. Minneapolis, MN: Fortress Press; 2000.

[47] Perner J. Understanding the representational mind. Cambridge, MA: Institute of Technology Press; 1991.

[48] Nye R. Psychological perspectives on children's spirituality. Doctoral Dissertation, University of Nottingham, UK; 1998.

[49] Scarlett WG, Naudau D, Salonius-Pasternak D, Ponte I. Children's play. Thousand Oaks, CA: Sage; 2005. 
[50] Rosengren KS, Kalish CW, Hickling AK, Gelman $\mathrm{SA}$. Exploring the relation between preschool children's magical beliefs and causal thinking. BJ Dev Psychol, 1994; 12: 69-82.

[51] Kahn PH. Children's affiliations with nature: Structure, development, and the problem of environmental generational amnesia. In: Kahn $\mathrm{PH}$, Kellert SR, editors. Children and nature: Psychological, sociocultural, and evolutionary investigations. Cambridge, MA: MIT Press; 2002. p 93116.
[52] Hyun E. Teachable moments: Reconceptualizing curricular understandings. New York: Peter Lang; 2006.

[53] Nabhan GP, Trimble S. The geography of childhood. Boston: Beacon Press; 1994.

[54] Bosacki S. Theory of mind or theory of the soul? The role of spirituality in children's understanding of minds and emotions. In: Erricker J, Ota C, editors. Spiritual education: Cultural, religious, and social differences. 2001; p. 156-69. 